\title{
ROLE OF RESOURCE-BASED ENTREPRENEURSHIP DEVELOPMENT TO INCREASE COMPETITIVENESS OF TRADITIONALLY WOVEN SARONG CREATIVE INDUSTRY
}

\author{
Zakiyah Zahara*, Nersiwad \\ Faculty of Economics, University of Tadulako, Indonesia \\ *E-mail: zahriakhoirunnisaa@rocketmail.com
}

\begin{abstract}
The objectives of the study were to describe position of traditionally woven sarong creative industry in Donggala in business competition based on both internal aspects (strength and weakness) and external ones (opportunity and threats), and role of resource-based entrepreneurship development to improve competitiveness of the traditionally woven sarong creative industry in Donggala. In order to meet the objectives, the study used SWOT and Moderating Regression Analysis (MRA). The findings showed that the strength of the Donggala woven sarong industry was the sarong had indigenous Central Sulawesi pattern, it was part of the rural society and was traditionally made. The weaknesses were the sarong pattern and design had yet been touched by modern technology, its color faded away easily during laundry and it was only sold in the local areas. The opportunities were the sarong may become alternative souvenir from Central Sulawesi and development of creative economy was widely discussed recently. The threat was there were various types and patterns of sarong in the market; and entrepreneurship was moderating variables between resourcebased strategy and competitiveness of Donggala woven sarong creative industry; the level of significance was 0.001 and the R-Square was 0.803 .
\end{abstract}

\section{KEY WORDS}

Entrepreneurship, competitiveness, creative industry, traditionally woven sarong.

Creative industry is the fourth wave economics that relies on creativity, culture, and cultural heritage and environment (Yudoyono, 2007). In addition, creative industries are local economic resources predicted to be able to meet the short and medium-term national basic economic issues, namely relatively low economic growth post crisis (average of only $4.5 \%$ per year), high unemployment rate (9-10\%), high poverty rate (16-17\%) (Pangestu, 2012). Based on the data from Portal Indonesia Kreatif (2010), within four years, the contribution of the creative industry to the economics keeps increasing for example contribution of creative industry towards the Gross Domestic Product (7.29\%), national exports $(9,25 \%)$, labor $(8,553,365$ people).

The important role of creative industry for the national economics does not go hand-inhand with its competitiveness. Chairman of the ASEAN Competitiveness Institute, Pardede (2013) revealed that in terms of competitiveness, Indonesia ranked below other South-East Asian countries. In terms of product competitiveness, Indonesia ranked $46^{\text {th }}$ globally, while Singapore ranked 2nd, Malaysia ranked 21st, Thailand ranked 39, Vietnam ranked 65th and the Philippines ranked 75th. It indicates the national product competitiveness is below Malaysia, Thailand and Singapore. It means Indonesia is facing big challenge that is to increase the national competitiveness in order to compete globally. Such condition illustrates dynamic and fierce business competition creative industry has to deal with. As the effect, the underlying question is how competitive business sense can be developed and improved?

Porter (2008) argued that competitiveness is the heart of business performance in order to compete, evolve and survive business competition. The finding of Black and Boal (1994)'s study stated that resource-based strategies had significant influence towards competitive advantage of a company. Mosakowski (1993) stated without entrepreneurship, small industry would not be able to survive the business competition even though it was able to maximize its resources. Emilia and Zuzana (2006) postulated that, ideally, implementation of strategy was integration of strategic and entrepreneurial attributes (entrepreneurial-based 
strategy). According to Lee and Peterson (2000), entrepreneurship orientation referred to entrepreneurial activity that includes methods, practices, decision-making styles used to take entrepreneurial action. Further, Miler (1978) explained success of small industry was determined by entrepreneurial orientation. Based on Koh (1996), entrepreneurial characteristics were innovative, courage to take risks and tolerant of ambiguity. Wiklund (1999) proved that the courage to take risks, innovation and proactive attitude would allow small industry to win business competition. Therefore, developing entrepreneurship is a relevant solution to improve competitiveness of creative industries.

One of national creative industries struggling to survive business competition is traditionally woven sarong industry in Donggala. Donggala woven sarong is craft passed down from generations to generations among people in Donggala, Central Sulawesi. The traditionally woven sarong is unique as it is made from natural silk fiber with various indigenous, interesting colors and patterns. The sarong was made by female weaver living in rural areas using traditional tool called balida. However, the traditionally woven sarong creative industry in is facing some setback in terms of sales and development; there is a threat that the industry will extinct. These happen because there are numerous types of sarongs with various pattern and different prices in the market; the traditionally woven sarong has to compete against them. Lack of innovation makes it more challenging for the creative industry of sarong in Donggala to survive the business competition.

Considering the importance of developing and improving competitiveness of the traditionally woven sarong industry in Donggala, a resource-based model of which purpose is to develop competitiveness of the creative industry is needed so that eventually, there is an increase in public welfare in Donggala.

Statement of Problem. Based on the background, statement of the problems are as follow:

1. How is the position of traditionally woven sarong creative industry in Donggala in business competition based on internal (strength and weakness) and external aspects (opportunity and threats)?

2. How is the role of resource-based entrepreneurship development to improve competitive ability of the traditionally woven sarong creative industry in Donggala?

\section{LITERATURE REVIEW}

Creative Industry. Alvin Toffler's theory states that the wave of human civilization is divided into three waves. The first wave is the century of agriculture. The second wave is the industrial age and the third wave is the information age. Until recently, human civilization stops at the third wave according to Toffler. However, others theories develop. Human civilization has entered fierce competition and globalization recently, known as the 4th wave. Some experts call it Knowledge-based Economy and some others call it Creative-oriented economics (Nenny, 2008).

Definition of creative industry according to the Ministry of Trade in the 2007 creative industry mapping stated in Pengembangan Ekonomi Kreatif Indonesia 2025, a book about development of the national creative economics in 2025 (2008) is industries derived from the utilization of creativity, skills, and individual talents to create prosperity and employment through creation and utilization of creativity and individual ideas.

Entrepreneurship. Hisrich, et.al. (2008) states that entrepreneurship is process of creating new things and at the same time, taking risks and expecting returns. Furthermore, Tunggal (2004) argues that entrepreneurship is a creative act of building value from something that is practically non-existent, seeking opportunities with resources or with limited resources, and taking calculated risks.

Entrepreneurship is influenced by skill, ability, or competence (Hebert and Link, 1988). Entrepreneurial orientation is related to psychometric aspects seen from its innovation, proactive nature and risk-taking courage (Kreiser, et.al., 2002). Through entrepreneurial character, in the form of risk-taking, innovative and proactive entities, a company is able to win business competition (Wiklund, 1999). 
Resource-based Strategy. Developing competitive ability of small industry is complex process, and requires strategy. One of the strategies to improve competitive ability is resource-based strategy. Mosakowski (1993) reveals that resource-based strategy is internal resource-based strategy superior to five resources, namely finance, physical, human, technology, and reputation of organization. Based on Grant (1991), characteristics of the five resource-based strategies have contribution in increasing strategic value of a product or competitive advantage simultaneously. Findings of Schroeder, et.al., (2002) reveals that dimension of resources, finance, physical, human, technology, and reputation of organization, is main attention of a company to achieve competitive advantage of its products, which is ability to make significant profit using internal resources the company has in an attempt to give similar or better value to customers with lower price than its competitor.

Competitiveness. Companies are said to have a competitive advantage if they have advantages over their competitors to attract customers and can survive pressures from business competition (Jogiyanto, 2005). Based on the theoretical concept, the core of competitive advantage that company should have is advantage competitors do not have and ability to win market competition. David (2006) argues that competitive advantage is anything companies execute better than their competitors. Based on Jogiyanto (2005), competitive advantage may be derived from having better position in the market compared to competitors and this depends on the strategies adopted by a company. Oliver (1997) states that the important thing is not how much resources and capabilities company has, but how it develops and utilized the resources and capabilities in order to make significant contribution and avoid business failure.

Previous Studies. Koh (1996) conducted a study entitled Testing hypotheses of entrepreneurial characteristics. The purpose was to test hypothesis related entrepreneurship characteristics. More particularly, the study investigated whether or not entrepreneurship tendency had significant relationship with need for achievement, locus of control, risk-taking tendency, ambiguity tolerance, confidence and innovation. T-test and logit analysis in 0.05 level of significance showed that those having entrepreneurship characteristics tend to be more innovative, more ambiguity tolerance, higher tendency to take risk compared to those who did not entrepreneurship characteristics.

Vitale, et.al., (2003) conducted empirical analysis entitled Entrepreneurial Orientation, Market Orientation and Performance in Estabilished and Start Up Firms. It evaluates the relationship between entrepreneurial orientation, market orientation and small industry performance in detail. The finding was interaction between entrepreneurial orientation and market orientation had positive, significant influence towards the business performance.

Ireland and Webb (2007) of which study entitled Strategic Entrepreneurship: Creating Competitive Advantage through Streams of Innovation showed that entrepreneurship strategy was an approach that served company well, in the attempt to achieve competitive advantage as qualified performance both currently and in the future.

The title of Ferreira and Azevedo (2007)'s study was Entrepreneurial Orientation as a Main Resource and Capability on Small Firm's Growth. The finding revealed that influence of resource and capability in developing small-scale industries. Entrepreneurial orientation was essential factor in connecting resource and capability towards growth of small companies.

Based on the previous studies, the study would analyze and integrate the findings of the previous studies in a concept that developed resource-based entrepreneurship in the traditionally woven sarong creative industry in Donggala.

\section{METHODS OF RESEARCH}

Research Design. Based on the specific objective and target of the study, the study was explanatory research using survey method. The survey was conducted towards the traditionally woven sarong creative industry in Donggala, Indonesia.

Setting and Object of the Study. The setting of the study was Donggala, a municipality in Central Sulawesi, Indonesia where traditionally woven sarong creative industry in 
Donggala was located. The object of the study was traditionally woven sarong creative industry in Donggala.

Sample and Unit of Analysis. The samples were 35 traditionally woven sarong creative industries in Donggala. The sampling method was random sampling. The unit if analysis was the traditionally woven sarong creative industry in Donggala while the respondents were the owners/ managers of the creative industry.

Variable. The variable consisted of independent, moderating and dependent variables. The independent variable was resource-based strategy (resource and capability), the moderating variable was entrepreneurship (innovative, proactive, and risk-taking ability), and the dependent variable was competitiveness (financial, differentiation and focus).

Table 1 describes the variables in a more detail manner.

Table 1 - Operation Variable Identification

\begin{tabular}{|c|c|c|c|}
\hline Variable & Indicator & Item & Source \\
\hline \multirow{5}{*}{$\begin{array}{l}\text { Resource-Based } \\
\text { Strategy (X1) }\end{array}$} & \multirow{3}{*}{ Resources (X.1.1) } & $\begin{array}{c}\text { Financial resource (ability of small company } \\
\text { to increase their capital) }\end{array}$ & \multirow{5}{*}{ Hitt, et.al. (2001) } \\
\hline & & Reputation, religious ethics and law & \\
\hline & & $\begin{array}{l}\text { Human resource (skill, discipline, } \\
\text { compensation and commitment) }\end{array}$ & \\
\hline & \multirow{2}{*}{ Capability (X1.2) } & $\begin{array}{l}\text { Quality consistency (ability to maintain } \\
\text { consistency in terms of quality) }\end{array}$ & \\
\hline & & $\begin{array}{c}\text { Ability to learn (ability to learn and adopt } \\
\text { new knowledge) }\end{array}$ & \\
\hline \multirow{8}{*}{ Entrepreneurship (X2) } & \multirow{3}{*}{ Innovative (X2.1) } & Determine new market & \multirow{8}{*}{$\begin{array}{l}\text { Vitale, et.al. (2003) } \\
\text { and Sangen (2005) }\end{array}$} \\
\hline & & $\begin{array}{l}\text { Find non-product method to create value for } \\
\text { customer }\end{array}$ & \\
\hline & & $\begin{array}{c}\text { Find methods to create value for customer } \\
\text { by developing partnership with other } \\
\text { entrepreneurs }\end{array}$ & \\
\hline & \multirow{4}{*}{ Proactive (X2.2) } & Proactive in introducing new product & \\
\hline & & Proactive in introducing new service & \\
\hline & & Proactive in developing partnership & \\
\hline & & $\begin{array}{l}\text { Proactive in increasing product and service } \\
\text { quality }\end{array}$ & \\
\hline & Risk (X2.3) & Preventing failure & \\
\hline \multirow{4}{*}{ Competitiveness $(\mathrm{Y})$} & $\begin{array}{c}\text { Financial } \\
\text { Advantage (Y1) }\end{array}$ & Advantage related to cost for production & \multirow{4}{*}{ Porter (2008) } \\
\hline & \multirow{2}{*}{$\begin{array}{l}\text { Differentiation } \\
\text { (Y2) }\end{array}$} & $\begin{array}{l}\text { Having different product from that of } \\
\text { competitors }\end{array}$ & \\
\hline & & $\begin{array}{l}\text { Having different service from that of } \\
\text { competitors }\end{array}$ & \\
\hline & Focus (Y3) & $\begin{array}{l}\text { Focus on few customers/ buyers purchasing } \\
\text { large quantity }\end{array}$ & \\
\hline
\end{tabular}

Data Analysis. Based on the purpose of the study, the data analysis consisted of two parts, SWOT and MRA (Moderated Regression Analysis) analyses.

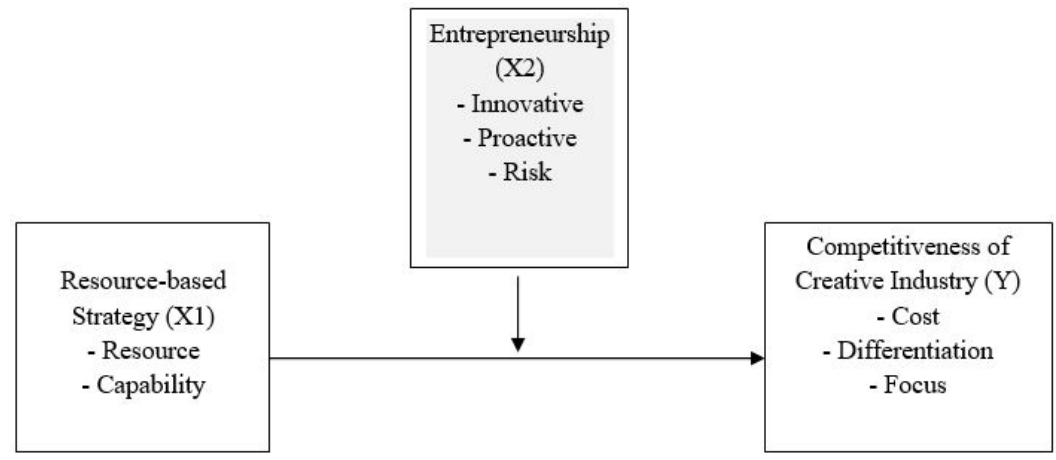

Figure 1 - MRA Model 
SWOT is identifying various factors systematically to be able to develop strategy. It is based on logic maximizing opportunity but at the same time, minimizing weakness and threat. SWOT analysis compared external and internal factors (Rangkuti, 2005).

The following was Moderated Regression Analysis (Liana, 2009). MRA is application for multiple linear regression analysis in which the equation contains interaction or moderating variable (multiplication of two or more independent variables). The model of analysis in line with the objectives of the study was seen from Figure 1.

\section{DISCUSSION OF RESULTS}

Position of the Donggala Woven Sarong Creative Industry in the Market. In order to describe position of the creative industry in the market, one may use two perspectives, strength and weakness as well as opportunity and threat in developing the industry. Table 2 describes the strength, weakness, opportunity and threat of the traditionally woven sarong industry in Donggala.

Table 2 - SWOT of Donggala Woven Sarong

\begin{tabular}{|l|ll|}
\hline \multicolumn{1}{|c|}{ Strength } & & \multicolumn{1}{c|}{ Weakness } \\
\hline - Unique pattern & - Conventional pattern and designed \\
- Part of culture for the natives & - Easily faded fabric \\
- Traditionally woven & - Local market \\
\hline Supported by the local government & Opportunities & \multicolumn{1}{c|}{ Threats } \\
\hline - Indigenous souvenir from Central Sulawesi & & - Various types and pattern of sarong in the market \\
- Public need of sarong & - Other sarongs were relatively affordable \\
- Need for empowering creative economics & - Other sarongs had modern pattern and design \\
\hline
\end{tabular}

Traditionally woven sarong creative industry in Donggala had some strength, weakness, opportunities and threats. The strength of the donggala woven sarong industry is the sarong has indigenous Central Sulawesi pattern, it is part of the rural society and is traditionally woven. The weaknesses are the sarong pattern and design have yet been exposed to modern technology, its color fades away easily during laundry and it is only sold in the local areas. The opportunities are the sarong may become alternative souvenir from Central Sulawesi and development of creative economy is a frequently discussed topic recently. The threat is there are various types and patterns of sarong in the market.

Role of Entrepreneurship Development. The term entrepreneurship in the study had three indicators, namely:

1. Innovative:

- Determine new market;

- Find non-product method to create value for customer;

- Find methods to create value for customer by developing partnership with other entrepreneurs.

2. Proactive:

- Proactive in introducing new product;

- Proactive in introducing new service;

- Proactive in developing partnership;

- Proactive in increasing product and service quality;

3. Risk:

- Preventing failure.

Based on the three indicators, MRA connecting the resource-based strategy, entrepreneurship and competitiveness of the sarong industry was conducted. The result of the MRA was seen from Figure 2.

Figure 2 showed that resource-based strategy (X1) had significant influence towards competitiveness of Donggala sarong creative industry $(Y)$. Furthermore, entrepreneurship 
(X2) also had significant influence towards competitiveness of Donggala sarong creative industry $(\mathrm{Y})$. The R-square was 0.506 .

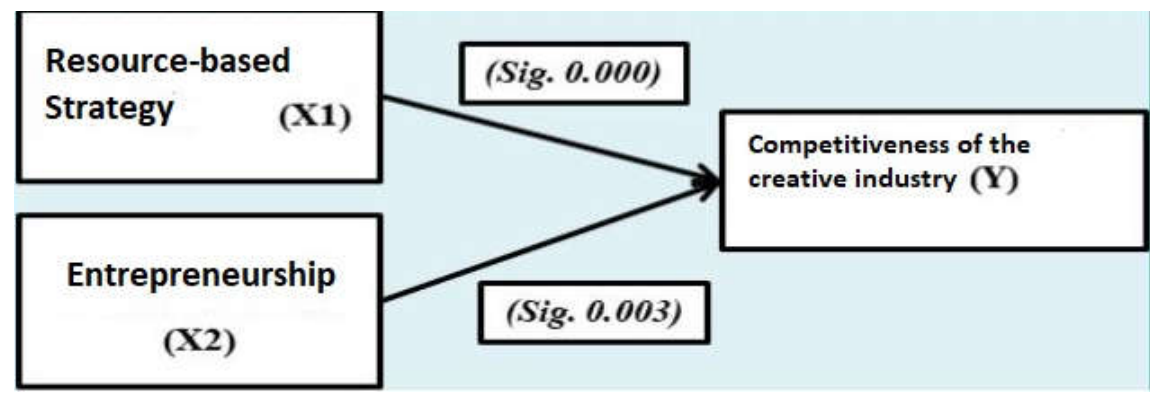

Figure 2 - Relationship between Resource-based Strategy and Entrepreneurship towards Competitiveness of the Creative Industry

The following procedure was to conduct MRA to describe the role of resource-based entrepreneurship development to increase competitiveness of the traditionally woven sarong creative industry in Donggala. The result of MRAwas as follow:

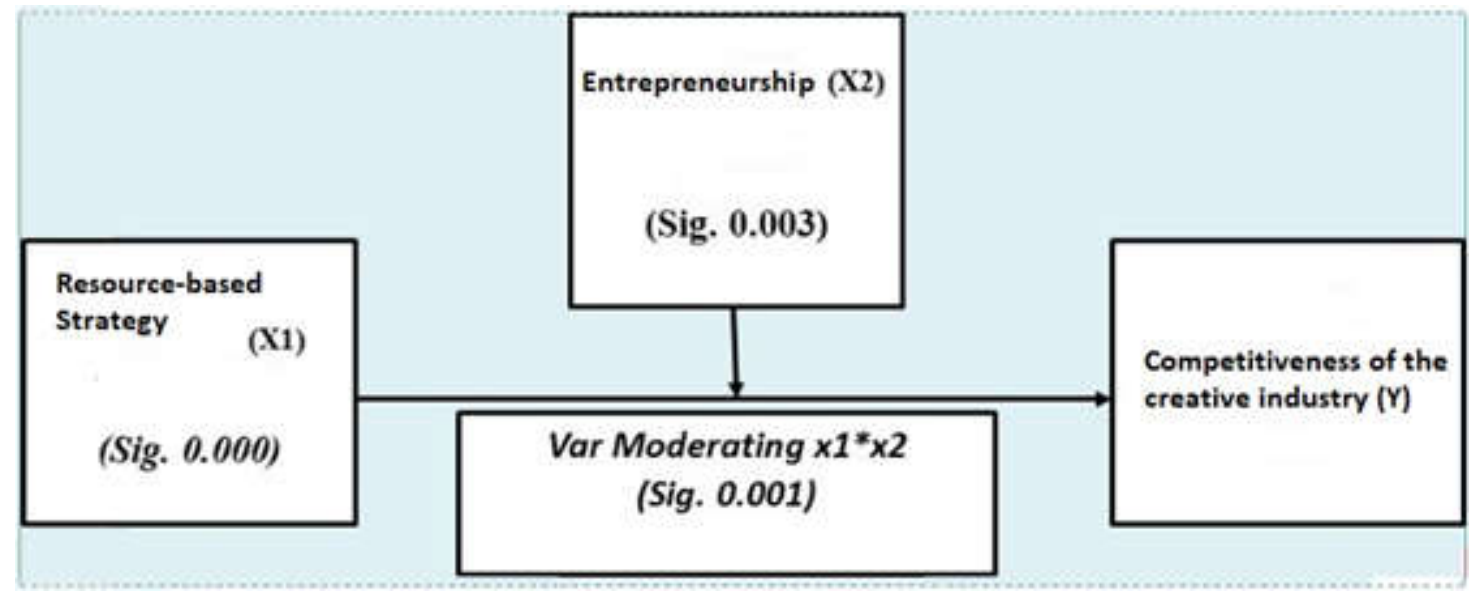

Figure 3 - Role of Resource-based Entrepreneurship Development to Increase Competitiveness Traditionally Woven Donggala Sarong Creative Industry

Figure 3 showed that entrepreneurship was moderating variable of the relationship between resource-based strategy and competitiveness of Donggala sarong creative industry. The level of significance was 0.001 and the R-Square was 0.803 .

R-Square of model $2>$ model 1 , meaning that the role of entrepreneurship was to strengthen the relationship between resource-based strategy and competitiveness of Donggala sarong creative industry.

\section{CONCLUSION}

Based on the discussions above, the conclusion is as follow:

The strength of the donggala woven sarong industry is the sarong has indigenous Central Sulawesi pattern, it is part of the rural society and is traditionally woven. The weaknesses are the sarong pattern and design have yet been exposed to modern technology, its color fades away easily during laundry and it is only sold in the local areas. The opportunities are the sarong may become alternative souvenir from Central Sulawesi and development of creative economy is a frequently discussed topic recently. The threat is there are various types and patterns of sarong in the market.

The role of entrepreneurship is to strengthen the relationship between resource-based strategy and competitiveness of the Donggala woven sarong creative industry. 


\section{REFERENCES}

1. Black, J. A., \& Boal, K. B. 1994. Strategic resources: Traits, configurations and paths to sustainable competitive advantage, Strategic Management Journal, 15: 131-148.

2. David, Fred R. 2006. Manajemen Strategi. Buku 1, Edisi kesepuluh. Jakarta : Salemba Empat.

3. Emilia, P., \& Zuzana, P. 2006. Competitive strategy and competitive Advantages of small and midsized Manufacturing enterprises in Slovakia, E-Leader, Slovakia.

4. Ferreira \& Azevedo, 2007. Entrepreneurial Orientation as a main Resource and Capability on Small Firm's Growth, MPRA Paper No. 5682, posted 10. November 2007 02:56 UTC

5. Grant, R. M. 1991. The Resource-Based Theory of Competitive Advantage: Implications for Strategy formulation, California Management Review; Spring 1991; 33, 3; ABI/INFORM Global pg. 114

6. Hébert, R.F. \& A.N. Link. 1988. The Entrepreneur, Mainstream Views and Radical Critiques, Praeger, New York.

7. Hisrich R. D, Peters, M. P, \& Shepherd DA. 2008. Entrepreneurship (7th International Edition). McGraw-Hill.

8. Hitt, Michael A. 2001. Manajemen Strategis: Daya Saing \& Globalisasi. Terjemahan Salemba Empat, Jakarta

9. Ireland, R. D \& Webb, J. W. 2007. Strategic Entrepreneurship: Creating Competitive Advantage Through Streams Of Innovation, Business Horizon (2007) 50, 40-59.

10. Jogiyanto. 2005. Sistem Informasi Strategik untuk Keunggulan Kompetitif. Yogyakarta : CV. Andi Offset.

11. Kreiser, P. M., L. D. Marino, \& K. M. Weaver. 2002. Assessing the Psychometric Properties of the Entrepreneurial Orientation Scale: A Multi-Country Analysis, Entrepreneurship Theory \& Practice 26 (4): 71-94.

12. Lee, S.M. \& Peterson, S. 2000. Culture, entrepreneurial orientation, and global competitiveness, Journal of World Business, 35: 401-416.

13. Liana, Lie. 2009. Penggunaan MRA dengan SPSS untuk Menguji Pengaruh Variabel Moderating terhadap Hubungan antara Variabel Independen and Variabel Dependen, Jurnal Teknologi Informasi DINAMIK Vol ume XIV, No.2, July 2009 : 90-97

14. Miller, D. \& Friesen, P. H. 1978. Archetypes of strategy formation, Management Science, 24:921-933.

15. Mosakowski E. 1993. A resource-based perspective on the dynamic strategyperformance relationship: an empirical examination of the focus and differentiation strategies on entrepreneurial fi rms, Journal of Management 19(4): 819-839.

16. Nenny, A. 2008. Industri Kreatif, Jurnal ekonomi Desember 2008 Volume XIII No. 3 pp. 144-151.

17. Oliver, C. 1997. Sustainable competitive advantage:Combining institutional and resourcebased Views, Strategic Management Journal, Vol. 18:9, 697-713.

18. Pangestu, M. E. 2012. Pengembangan Ekonomi Kreatif di Indonesia 2025, Department of Trade of Indonesia, Jakarta.

19. Pardede, S. 2013. Daya Saing Produk Indonesia Di Bawah Malaysia, Singapura and Thailand, Neraca. Malaysia Singapura and Thailand,

20. Porter, M.E. 2008, The Five Competitive Forces That Shape Strategy, Harvard Business Review, January 2008, pp. 79-93.

21. Rangkuti, F. 2005. Great Sales Forecast For Marketing, Penerbit PT. Gramedia Pustaka Utama, Jakarta

22. Sangen, M. 2005. Pengaruh Orientasi Kewirausahaan, Orientasi Pasar and Budaya terhadap Kinerja Usaha Kecil Etnis Cina, Bugis, Jawa, And Banjar (Studi Pada Industri Pengelolahan pangan di Kalimantan Selatan), Disertation, Graduate Program, Brawijaya University, Malang 
23. Schroeder, S.R., Oster-Granite, M.L. \& Thompson, T. (Eds.) 2002. Self-injurious behavior: Gene-brain-behavior relationships, Washington, D.C.: American Psychological Association.

24. Tunggal, A. W. 2004. Manajemen Strategik. First Edition, Harvarindo, Jakarta.

25. Vitale R, Giglierano J, \& Miles M. 2003. Entrepreneurial Orientation, Market Orientation, and Performance in Estableshed and Startup Firms.

26. Wiklund, J. 1998. Entrepreneurial orientation as predictor of performance and entrepreneurial behavior in small firms. In P. D. Reynolds, W. D. Bygrave, N. M. Carter, S. Manigart, C. M. Mason, G. D. Meyer, \& K. G. Shaver (Eds.), Frontiers of entrepreneurship research (pp. 281-296). Babson Park, MS: Babson College.

27. Yudoyono, S.B. 2007. Kembangkan Ekonomi Gelombang Keempat, http://www.presidenri.go.id/index.php/fokus/2007/07/11/2009.html 